\title{
The theory of everything
}

\author{
By Li xiaohong
}

\begin{abstract}
: is there a unified theory of nature, the theory of everything, behind the natural phenomena observed by different disciplines and dispersed?

Here is the formula for chord language, similar to Planck's formula.

$\mathrm{S}=\mathrm{HV}$, ( $\mathrm{S}=$ semitone, $\mathrm{H}=$ average law constant, $\mathrm{V}=$ frequency), minimum discrete value.

$\mathrm{I}=\mathrm{H}^{\wedge} \mathrm{n} \cdot \mathrm{V}(\mathrm{I}=$ interval, $\mathrm{n}=$ interval value), allowing discrete values.

$\mathrm{C}=\mathrm{H}^{\wedge} \mathrm{n} 1, \mathrm{n} 2, \mathrm{n} 3, \mathrm{n}^{*} . \mathrm{V}(\mathrm{C}=$ chord$)$, discrete value spectrum.
\end{abstract}

Chord language consists of chord spectrum, with quantum, string (opening, closing string, N string), symmetry, mirroring and other mathematical, geometric features, manifested in music (time), painting (space), life (meridian), spiritual and other phenomena, has accumulated for thousands of years;a more complete mathematical model;can be observed and verified; It should be a feature of the theory of everything.

Similarly, physics also has the characteristics of chord language (quantization, string theory, etc.). Is it a phenomenon of chord language?

Music (time), painting (space) contains the theory of everything?

Key words: chord language, chord space-time, theory of everything, quantum, string, music, painting, meridian

\section{Chord language}

Chord language phenomena include: music, painting (chord geometry), life (meridian), time and space.

Humans have two sets of language systems: naming symbolic language (symbolic logic) and chord language (chord logic), the former being artificial symbolic languages and the latter being natural coding languages, based on different principles and processes.differences between the two languages can lead to differences in human understanding.

Chord language has been known for thousands of years, and its mathematical model can be traced back to ancient Greece.the pentatonic scale of Pythagoras.through the observation and accumulation of past generations of musicians, gradually perfect; the Yin and Yang $(+,-)$ attributes of chord language are observed in meridian theory.numerous classic works left in the history of 
painting have accumulated material for the grammar, semantic analysis and research of chord space.

\section{About art}

Most disciplines (science, philosophy, literature, etc.) use naming symbolic language, but music and painting use chord language (quantum language). The significance of this feature is that it shows the physical layer of the spirit.

Music, painting is a phenomenon of chord language, which is represented by isomorphism, symmetry and mirror system mathematically.

Music, painting is also a chord space-time system, painting expression space, music expression time, interdependence, chord space-time can only be the common observation of both.

Music has a scientific form such as quantitative and mathematical expression, while painting is still a subject of experience and intuition, and the construction of the subject is not completed.

Chord language is also space-time language. Understanding space-time is the common need of science and art.

\section{About science}

Human beings have two sets of space-time cognition and expression system: reference frame space-time and chord space-time (quantum and string space-time), scientific use of reference frame space-time, music, painting, meridian and so on use chord space-time.

Chord space-time is a scientific blind spot.

Reference frame space-time: the reference frame is measured and assigned by external measurement tools, such as ruler, clock, etc., and the background reference frame is assigned to describe the motion.

Chord Space-Time (Quantum Space-Time): Expressed by chord coding, time and space are the energized effects of quantization. The two are symmetric and mirror images of each other, independent of external clocks, rulers, and background reference systems.

Reference frame space-time will block chord space-time (quantum space-time), for example:

Using clocks, rulers and other external measures to measure chord space-time system (such as works of Beethoven, Mozart, van gogh and monet), the measured values can establish a 
theoretical model of space-time, but there is no space-time chord coding, energy form and function in the space-time theory based on the reference system.

The reference frame space-time and chord space-time (quantum space-time) are based on different principles and are not completely compatible, which can cause confusion in physics.

In painting, chords show spatial semantics: open strings (major triads), closed strings (minor triads), $\mathrm{n}$-dimensional strings (Discord), three chords generate all spatial states and interactions; this result, based on drawing observations, can be verified -- this is what string theory, $M$ theory, needs to know.

Chord language also exists in life phenomenon, which is manifested as "meridian science", which should be paid attention to in life science.

\section{Other}

Chord language is a common blind spot in human cognitive activities for two reasons:

1. Differences in principles and methods between the two languages: chord language usually occurs in the background and bottom layer of symbolic language, which does not depend on the symbolic language system and cannot be perceived by reason, resulting in the form and effect of chord language cannot be observed.

2. Chord language relies on internal observation (self-observation), such as music, painting, meridian science, etc., which is not within the scope of science at present.

New knowledge points in the book: chord language, chord space-time, chord painting, chord mathematics, chord life.

Involve existing knowledge points: music theory, music mathematics, color theory, physics, life, meridian of traditional Chinese medicine.

Note: this is the introduction to language of chords. ISBN:9781370273348 


\section{Chinese version}

\section{万物理论}

由不同学科、分散观察到的自然现象后面, 是否存在统一的自然原理, 万物理论?

下面是和弦语言公式，与普朗克公式相似。

$\mathrm{S}=\mathrm{HV}$, ( $\mathrm{S}=$ 半音程, $\mathrm{H}=$ 平均律常数, $\mathrm{V}=$ 频率), 最小离散值。

$\mathrm{I}=\mathrm{H}^{\wedge} \mathrm{n} . \mathrm{V}$ ( $\mathrm{I}=$ 音程, n=音程值), 允许离散值。

$\mathrm{C}=\mathrm{H}^{\wedge} \mathrm{n} 1, \mathrm{n} 2, \mathrm{n} 3, \mathrm{n} * \mathrm{~V}$ ( $\mathrm{C}=$ 和弦), 离散值频谱。

和弦语言由和弦频谱构成, 具有量子化, 弦 (开弦, 闭弦, $N$ 弦), 对称, 镜像等数学、

几何特征, 表现在音乐 (时间), 绘画 (空间), 生命（经络学）、精神等现象中, 已有几千 年认识积累; 较完整的数学模型; 可观察、验证; 应是万物理论特征。

同样, 物理学也有和弦语言特征 (量子化, 弦理论等), 是和弦语言现象吗?

音乐（时间），绘画（空间）中包含着万物理论?

关键词: 和弦语言, 和弦时空, 万物理论, 量子, 弦, 音乐, 绘画, 经络

\section{和弦语言}

和弦语言现象包括: 音乐, 绘画 (和弦几何), 生命 (经络学), 时空。

人类有两套语言系统: 命名符号语言 (符号逻辑) 与和弦语言 (和弦逻辑), 前者是人 工符号语言，后者是自然编码语言，基于不同的原理、过程。两种语言的差异可导致人类的 认识差异。

和弦语言的认识已有几千年历史, 其数学模型可追溯到古希腊时期; 如: 毕达哥拉斯的 五声音阶。经过历代音乐家的观察积累, 逐渐完善; 经络学观察到和弦语言的阴、阳（+、 一) 属性; 绘画史上留下的无数经典作品, 为和弦空间的语法, 语义分析, 研究积累了素材。

\section{关于艺术}

多数学科 (科学、哲学, 文学等) 使用命名符号语言, 但音乐、绘画使用和弦语言 (量 子语言），这一特征的重要意义是：它显示出了精神的物理层。

音乐, 绘画都是和弦语言现象, 数学上表现为同构、对称、镜像系统。 
音乐, 绘画也是和弦时空系统, 绘画表达空间, 音乐表达时间, 相互依存, 和弦时空只 能是两者的共同观察结果。

音乐已具有定量、数学表达等科学形式, 而绘画仍是依赖经验、直觉的术科, 未完成学 科建设。

和弦语言也是时空语言, 理解时空是科学与艺术的共同需要。

\section{关于科学}

人类有两套时空认知，表达系统：参考系时空与和弦时空（量子、弦时空），科学使用 参考系时空，音乐、绘画、经络学等使用和弦时空。

和弦时空是科学的盲区。

参考系时空：由外部度量参考系：尺子，时钟等工具测量赋值，指派背景参考系描述运 动。

和弦时空（量子时空）: 由和弦编码表达, 时、空是量子化的能量作用, 两者互为对称 镜像，不依赖外部时钟，尺子，背景参考系。

参考系时空会屏蔽和弦时空（量子时空），举一个例子：

用时钟，尺度等外部度量参考系测量和弦时空系统（如：贝多芬、莫扎特，梵高、莫奈 的作品），从测得数值可建立时空理论模型，但基于参考系的时空理论中没有时空的和弦编 码、能量的形式和作用。

参考系时空与和弦时空（量子时空）基于不同原理，不能完全兼容，这会给物理学带来 困惑。

在绘画中，和弦表现出空间语义：开弦（大三和弦），闭弦（小三和弦）， N 维弦 (不 协和弦），三种和弦产生所有空间状态、相互作用；这一结果基于绘画观察，可以验证一一 这是弦理论, M 理论需要知道的事实。

和弦语言也存在于生命现象中，表现为 “经络学”，这是生命科学应注意的。

\section{其他}

和弦语言是人类认识活动的常见盲区，有两个原因:

1、两种语言的原理、方法差异：和弦语言通常发生在符号语言的后台、底层，不依赖 符号语言系统，无法被理性觉察，导致和弦语言的形式和作用无法被观察。 
2、和弦语言依赖内观察 (自观察), 如: 音乐, 绘画, 经络学等, 目前不在科学范围之 内。

全书新增知识点: 和弦语言, 和弦时空, 和弦绘画, 和弦数学, 和弦生命。

涉及已有知识点: 音乐理论, 音乐数学, 色彩理论、物理, 生命, 中医经络学。 注: 本文为《和弦语言》一书的序言。 